\title{
Globalization and Knowledge Production in the World: A Critical Analysis of the Place of Africa
}

\author{
Kelvin Bribena*
}

Faculty of Law, Niger Delta University, Bayelsa State, Nigeria

\begin{abstract}
Globalization has impacted unprecedentedly on global knowledge production. The politics of knowledge production has taken a new dimension since the end of the Cold War era in which Euro-American ideals has continued to sweep around the world. The import of this is that there has been universalization of what constitutes knowledge and how it is produced. Development generally is patterned after the with the West as the ideal. Africa, a colonial construct has also been affected by the globalization of knowledge production. This paper adopts the qualitative research methodology with the analysis of extant academic works and other materials to make sense of the situation of Africa in the global politics of knowledge production. The paper notes that while Africa was just wriggling out of throes of colonialism politically and efforts at decolonizing knowledge at infancy, the onset of globalization has confined the continent to the backseat among other continents. It notes further that as a result of this, what constitutes knowledge, how it is produced and accessed in Africa remains Western. As a result of this African development is vainly patterned after her 'erstwhile' colonial masters. The whole idea of post-colonialism in Africa is misleading and knowledge production with which to forge ahead is perpetually colonial, hence Africa's unhealthy backwardness. The paper recommends that Africa needs not only to decolonise knowledge production but also assert its position in global politics of knowledge production in order to be in charge of its development.
\end{abstract}

Keywords: Globalization, Knowledge, Knowledge Production, Africa.

\section{INTRODUCTION}

New trend of information, models and theories toward enhancing knowledge and its circulation have been aided through globalisation leading to states and organisations tapping from global resources. This has made some states to be subservient and weak to the other leading to the global classification of states in the international system. The thesis of dependency, third world and developed states are coinage that sprang from the dominant of some countries over the other due to knowledge superiority. Available literature suggests that the root of this permutation and configuration of modern states can be traceable to the emergence of colonial system witnessed by some countries in the past centuries where the instrument of war, the Hobbian state of nature, slave societies, these and among others have play out leading to disorganised and disjointed societies (ObahAkpowoghaha el al., 2014). Vicious cycle of poverty has precipitated these countries and making them to be masters of production of raw materials and the zones for exploration of natural resources while those countries that are at advantage hemisphere have been able to assumed superiority over the others. In other words, colonial system has created artificial system that has permeated certain knowledge and philosophy which has been intensified through United Nations

*Address correspondence to this author at the Faculty of Law, Niger Delta University, Bayelsa State, Nigeria; E-mail: vojakoro@yahoo.com arrangement particularly the formation of the Security Council (ibid).

However, Africa as a continent in the globalised system has witnessed a lot of setback due to the earlier infiltration of the European Merchandise and this has made this continent an instrument of manipulation in the comity of nations. The African continent has been noted for the production of raw materials and the consumption of finished goods arising from the asymmetrical relations in the global system. Consequently, extant literature shown that the continent has been seen as place of 'dumping ground' due to overproduction of goods and services aided by increased production of knowledge emanating from European and Western countries. This process and formation has worsened due to borders' porousness, policy failure and security challenge in most African states (Obah-Akpowoghaha el al., 2014).

Consequently, the much-discussed globalization process of the present century refers mainly to the economic processes of globalization of markets for goods, capital and labour whereas the globalisation and production of knowledge is often considered as a mere presupposition or consequence of economic, political and cultural processes. But globalization involves knowledge in more significant ways in its scientific production process. Moreover, globalization and production of knowledge in the sense of a global interconnectedness of human knowledge is not only a phenomenon of the present age. Contemporary 
situation today may rather be understood as the result of historical processes that already comprise many dimensions characterizing modern globalization processes, each with its own peculiar constellation of economic, political, technical and cultural means of social cohesion. However, more details will be made below following different sections in this paper.

\section{LITERATURE REVIEW}

\subsection{Globalisation}

Recent discussions about globalization processes emphasize two apparently contradictory characteristics of such processes: homogenization and universalization, on one hand, and their contribution to an ever more complex and uncontrollable world, on the other (Renn and Hyman, 2013). Globalization processes such as the exchange of technology or migrations of people thus obviously presuppose the diffusion of knowledge: the knowledge of how to deal with the technical means transferred and the knowledge of how to establish life under new circumstances, respectively. Similarly, knowledge is clearly a consequence of globalization processes, just as the exchange of goods or the diffusion of a language also transport knowledge. Knowledge, however, does not just constitute one more aspect of globalization as a precondition and consequence, but represents a critical element of its development. It is in fact the globalization of knowledge as a historical process with its own dynamics that orchestrates the interaction of all the underlying layers of globalization. The globalization of knowledge not only constitutes a relatively autonomous process in its own right, but profoundly influences all other globalization processes-including the formation of markets-by shaping the identity of its actors as well as of its critics (Renn and Hyman, 2013).

\section{KNOWLEDGE}

A common theoretical language for addressing the issue of globalization of knowledge from a comparative perspective must be both expressively rich and structurally simple. It must draw on established insights from cognitive science, philosophical epistemology, anthropology, archaeology, historical disciplines including the history of science, the history of art and the social sciences; it must moreover encompass the full range of developmental processes implicated in the global spread of knowledge throughout history. No existing academic discipline provides all the tools required.
Knowledge is conceived here as the capacity of an individual, a group, or a society to solve problems and to mentally anticipate the necessary actions. Knowledge is, in short, a problem-solving potential. Knowledge is often conceived (especially in disciplines such as psychology, philosophy and the cognitive sciences) as something mainly mental and private. But from the historical and social viewpoint, it is necessary to consider knowledge as something that moves from one person to another: something that may be shared by members of a profession, a social class, a geographic region or even an entire civilization. From this perspective, knowledge and its movements may be mapped. Shared knowledge is especially important to the artistic, religious, legal and economic systems that constitute cultures; and knowledge travels along with artefacts and artistic styles, myths and rituals, laws and norms, goods and wealth. Not only is knowledge situated in time and space, but so too is thinking. Recently, the latter phenomenon has come to be studied in cognitive psychology under the term "distributed cognition" (Perry 2003). The range of knowledge forms with different degrees of reflexivity includes the following, strongly overlapping categories:

1. intuitive knowledge

2. practitioners' knowledge

3. symbolically represented knowledge

4. Introduction

5. technological knowledge (determined by ends)

6. scientific knowledge (determined by means)

7. second- and higher-order knowledge.

Technology, innovation, knowledge production and higher education have been identified as key ingredients for the successful development and progress of countries. Mokyr attributes Europe's growth and development in the 1700's, which resulted in the establishment of the 'gap' between Europe and the rest of the world, to technological progress. Information technology and innovation, the main basis for globalization, are in turn highly knowledge intensive (Muthayan, 2005). As technology drives globalization, knowledge (as opposed to labour) assumes an increasingly powerful role in production. The production of knowledge has been recognised as an essential factor for successful economic growth and competitiveness (Stromquist \& Monkman, 2000b, p. 12; 
Task Force on Higher Education, 2000, p. 17 cited in Muthayan, 2005).

Moreover, globalization of knowledge has wideranging effects on economic activity and labour worldwide. By moving developing countries closer to the production possibility frontier, it undermines the "North-South" model of trade that positions the comparative advantage of advanced countries in their dominance of high value added goods and services at the frontier of technology; affects the immigration of skilled workers; boosts pressures for higher labour standards; and influences the level of incomes and inequality within countries and across the globe. To the extent that knowledge is the key component in productivity and growth, its spread and creation is the one ring that rules them all of my title. Scholarly response to the changing nature of knowledge and its impact on the university differs. In a study by Freeman (2013), expresses concern that Mode 2 will signal the end of Mode 1 knowledge production --pure research-weaken the knowledge base in the long run or spell the end of the university, citing as evidence the rise of the entrepreneurial university. Others, like Delanty (2001cited in Freeman (2013), posit the view that although the university may have lost its position as the central producer of knowledge and be in danger of becoming a site of corporate capitalism, it remains an important knowledge producer amongst multiple producers. In addition, the university must assume the important function of facilitator of the increasingly public value of knowledge in the future (Delanty, 2001, p. 9, 116, 152; Gibbons et al., 1994, p. 7, 156; Willinsky, 2000 cited in Freeman, 2013). Delanty explains that the task of the university is to open up sites of communication in society, to institutionalize certain uncommon ideas, thus reversing the decline of the public sphere and enabling the democratization of knowledge instead (Freeman, 2013).

In his research, he further argued that several universities in the developing world (specifically in Africa) find it difficult to function, let alone improve the quality of and even publish research. In the first instance, they do not have adequate library facilities. Books and journal holdings are sparse and outdated; preventing academics from being acquainted with the latest research developments. This impinges negatively on their capacity to produce research, especially cutting edge research. The costs of library subscriptions to journals are exorbitant, especially when foreign exchange rates are taken into account. The developed nations also dominate the systems that distribute knowledge by controlling publishing houses: 34 industrialised countries with only $30 \%$ of the world's population produce $81 \%$ of the world's book titles. Hence, these countries define research paradigms and the foci of the field, rendering the rest of the world peripheral in determining the research agenda. Prohibitive factors to publishing in developing countries, which perpetuate dependency on the West include: costs of printing, lack of access to technology for printing, lack of clients for published journals, copyright regulations and costs, heavy teaching loads of academics, unsupportive research environments and language barriers. According to Altbach (1987), neocolonialism is maintained through foreign aid programmes and loan policies and is a factor that must be considered in any analysis of publishing in the Third World (p. 33).

Religions have been one of the most important conveyors of the globalization of knowledge and of science in the period between antiquity and the early modern era. With the rise of Buddhism in India and of Christianity and Islam in the West (as well as Judaism after the destruction of the Second Temple), religion became decoupled from the state to a previously unparalleled degree, emerging as a source of authority separate from and potentially in conflict with that of the state, thus developing a potential for global spread (world religions). This new development set the stage for the accumulation and transmission of knowledge which, while nonetheless always extrinsically motivated, would neither be confined to local networks nor be inseparable from immediate contexts of application, and thus free to be repurposed or translated to new contexts. The extent to which this possibility was realized remained largely contingent on the emergence of a social network that supported the production and dissemination of knowledge. Hubs in this network were typically flourishing trade or religious centres, or capital cities of large empires (Renn and Hyman, 2013).

\section{GLOBALIZATION OF KNOWLEDGE AND KNOWLEDGE PRODUCTION}

The rapidity with which developing countries expanded their higher education systems and graduated huge numbers of workers in science, engineering and technology, and moved toward the frontier of science and innovation is one of the great surprises of the era of globalization. Part of the revelation of Muthayan's study (2005) Exhibit 1 records the number of students enrolled in tertiary education 
(college or university, including two year colleges) in developing and advanced countries from 1970 to 2010, based on data from UNESCO. In 1970 although developing countries constituted about $80 \%$ of the world population, they had $54 \%$ of university enrolments. As a result of the destruction that the Maoist Cultural Revolution wreaked on China's educational system, China had less than 300,000 college and university students. The other population giant India had 2.5 million students. Among advanced countries, the US was the pioneer in mass higher education. Although the US had about $6 \%$ of the world population, in 1970 twenty-nine percent of college or university students were American. Many other advanced countries had begun expanding their higher education systems in the 1960s but did not reach the US level of mass higher education until the 1990s. By 2010 , the division of university students and graduates around the world had changed markedly.

Developing countries had over three-quarters of university students. China enrolled 30 million students and graduated 5-6 million persons with university degrees, many in science and engineering. India was slower in expanding its higher educational system but still enrolled 21 million persons in 2010 and more than doubled the number of Indian Institutes for Technology from 1970 to 2010s. Other developing countries also invested heavily in university education, building new universities and expanding older ones. For example, the International Association of Universities (IAU) listed 82 institutions of higher education for Bangladesh in 2012 compared to the dozen or so that existed in the 1970s. This growth came about through the entry of many private universities as well as public institutions. Similarly the IAU reports that Chile had 90 Universidads and Instituto Professionals in 2012, which compares to 16 in the 1970 s. By the early 2000 s many advanced countries attained similar or higher rates of enrolment of persons of the relevant age in college and university than the US. Still, the share of tertiary students in advanced countries beyond the US began trending down as the advanced country share of world population fell and as developing countries increased enrolments rapidly. The US share of enrolments was $11 \%$ in 2010 and shrinking.

At the highest level of academic training, there was a similar pattern of globalization as many countries invested in doctorate programs. China increased the number of graduating PhDs in the natural sciences and engineering to exceed the number in the US in 2007 (though it fell short of the total science and engineering degrees due to much larger numbers of social science $\mathrm{PhDs}$ in the US). Among the European countries, Sweden graduated more S\&E PhDs per person in the relevant age group than the US while the EU overall graduated nearly twice as many natural sciences and engineering PhDs as did the US.5 Indeed, the number of American citizens getting PhDs did not change much in the 1990s and 2000s. What maintained US doctorate production were international students, who earned about one third of the PhDs in science and engineering in 2009 and accounted for over half of engineering, computer science, and physics doctoral degrees. To be sure, the quality of higher education in developing countries that were rapidly building up their universities and increasing enrolments fell below the quality of higher education in advanced countries. In Shanghai's Jiao Tong University ranking of universities 190 of the top 200 universities were Western (with five of the ten non-Western in the top 200 in China, including 2 in Hong Kong). And while the US share of degrees fell, US universities maintained their position as global leaders in higher education, holding $40 \%$ of the top hundred and $37 \%$ of the second hundred in the Shanghai ranking. The London Times Higher Education ranking of universities shows a similar pattern with 93 advanced country universities in its top 100 , and 43 in the US.

More relevant for the labour market, McKinsey's 2006 study of the supply of graduates around the world (published as Farrell, 2006) found that the recruiters of Western firms viewed only $13 \%$ of university graduates from 28 low wage countries, including China, India, and Brazil, as "suitable to work in a multinational company". The recruiters based their assessment on English language skills, cultural fit, and location near major centres with international airline connections. These factors could, however, be irrelevant to national firms operating in those countries, and even $13 \%$ of tens of millions of graduates creates a huge pool of talent for jobs at the multinationals. As McKinsey did not ask the recruiters the proportion of graduates from Western colleges and universities that met the standards of the multinationals, moreover, it is difficult to assess relative quality from these data.

\section{IMPACTS OF GLOBALIZATION OF KNOWLEDGE AND KNOWLEDGE PRODUCTION}

Globalization of knowledge has wide-ranging effects on production and labour worldwide. To the extent that knowledge is a key factor in production, the spread and creation of knowledge is critical to economic 
development, comparative advantage, the flow of labour and capital among countries, and the spread of labour standards and norms about worker rights. Operating with or through the other rings of globalization, the spread of modern technological knowledge has arguably contributed to increased inequality within countries as well as to the convergence of income per capita among countries. Consider first the impact of the globalization of knowledge and of research and development on the competitiveness of workers in advanced and African countries. Debates over trade treaties and intellectual property rights highlight the importance of higher level education and of the ability to create new technology in advanced countries as providing comparative advantage compared to developing countries and protecting workers from low wage competition. In the 1990s debate over the North American Free Trade Agreement (NAFTA), NAFTA advocates told Americans that Mexico would get labour-intensive industries with "bad jobs" that did not require much education while the US would get high tech industries with good jobs for well educated workers. As long as US workers maintained their years of schooling edge over Mexicans the US workers had nothing to fear from lower wage labour in Mexico.

This view of a permanent education edge as protecting US workers from competition has been undermined by the rapid growth of higher education in Mexico and developing countries worldwide and by the ability of firms to outsource the work of the highly educated along global value chains In the 1990s-2000s debate over the Agreement on Trade Related Aspects of Intellectual Property Rights (TRIPS) advanced countries sought to protect the patents, copy writes, and discoveries of the firms that developed new products and processes. The "North-South" or life cycle product model of trade develops the consequences of such protections for labour (Krugman, 1979). This model attributes the higher earnings of workers in advanced countries relative to the earnings of otherwise similar workers in developing countries to the advanced country monopoly of R\&D-induced technological change and production of technologically advanced goods and services. Firms pay workers more in the advanced North because the latest technology makes workers more productive than workers using older technologies in developing countries. The advanced country/developing country wage differential depends on the rate of technological advance in the North relative to the rate of imitation of technology in the South. Jones and Ruffin (2007) analyze the effects of technology transfer, which is a form of imitation of technology, on advanced countries under more complex conditions.

In their studies using certain models, Globalization of knowledge and knowledge creation obsolesces this model. To the extent that technological development depends on the absolute number of scientists and engineers or other highly educated workers rather than the ratio of such specialists to less skilled workers, highly populous developing countries with large numbers of S\&E workers can compete with advanced countries in high tech sectors. If China has 100,000 engineers working on green technology and France has 10,000 engineers, China is more likely to advance that technology than France. When multinational giants such as IBM and Microsoft first expanded research activities in China or India, their decisions made headlines. By the early 2010s, the availability of highly qualified workers at low cost had made it commonplace to locate research facilities in developing countries. With global production chains dispersing production worldwide, some analysts argue that the location of manufacturing in developing countries will itself lead to greater R\&D in those countries, as firms find that R\&D is more efficient in close proximity with the manufacturing facility. This reverses the causality on which the North-South model is built. Manufacturing attracts R\&D rather than R\&D attracting new manufacturing.

The evidence that globalization of knowledge has outrun the North-South model can be found not only in the greater dispersion of R\&D facilities worldwide described earlier but also in increased production and exports of high-tech products in developing countries (subject to the caveat that global supply chains make it difficult to assign products to countries). Panel A of Exhibit 5 shows a sizable shift in value added in knowledge and technology intensive industries from the US, EU, and Japan to the rest of the world between 1990 and 2010. With its huge investments in higher education and $R \& D$, China made a particularly large gain in its share of value added in the knowledge and technology intensive sectors. Panel B of Exhibit 5 shows an even greater shift in exports in high-tech goods from the US, EU, and Japan to other countries. Again China increased its share the most. In 20082009 the Obama Administration viewed green technologies as a way to restore US manufacturing jobs but soon discovered that China had become the leading place of production in some areas of solar technology. 


\section{IMMIGRATION OF HIGHLY SKILLED AND LESS SKILLED WORKERS}

Almost by definition developing countries have a surfeit of unskilled workers relative to other factors of production compared to advanced countries, and pay those workers less than they could earn if they worked in advanced countries. Accordingly, large numbers of less skilled workers migrate from Mexico, Central America, the Caribbean, and Latin America to the US, many without documentation. Similarly, advanced Europe is the destination of many less skilled workers from Eastern Europe, the Maghreb, and other parts of Africa. Such immigration helps balance factor proportions among countries, consistent with Hecksher-Ohlin patterns of trade. The surprise in immigration is that many highly skilled workers also migrate to advanced countries, adding to the imbalance in factor proportions via "brain drain". Underlying this flow are large wage differences across countries of workers with the same skills (Freeman and Oostendorp, 2000) that presumably result from the superior infrastructure and productive knowledge in advanced countries. International students are a major source of this migration. Students build job market skills and connections in the country in which they study that makes immigration easier. Some countries, such as Canada and Australia, give visas on the basis of skills, with Australia advantaging persons who obtain Australian degrees. In the US, over half of foreign-born science and engineering workers with a bachelor's degree, and over $2 / 3$ rds of foreign-born master's and $\mathrm{PhD}$ scientists and engineers obtained their highest degree in the US (Freeman, 2010b). Migration of highly educated workers to advanced countries strengthens their comparative advantage in skill-intensive sectors and reduces the incentive of multinationals to invest in $R \& D$ or other skill-intensive activities in developing countries. While outflows of educated workers can create substantial skill shortages for small Caribbean islands, Central American, or African countries, the movement of educated persons from highly populous developing economies to advanced countries is unlikely to have much adverse effects on the source country.

The number of migrants is modest compared to the increased numbers graduating from universities in those countries. With six million new university graduates every year and 28,000 new S\&E PhDs in China and with many Chinese getting doctorates in other countries, the loss of tens of thousands of bachelor's graduates or of hundreds of PhDs migrating to advanced countries barely slows the rapid increase in the pool of highly educated workers.

The migration of skilled immigrants to advanced countries has, moreover, advantages to developing countries. Some immigrants return to their birth countries with greater skills and income. Some move regularly between their birth countries and country of immigration, creating "brain circulation" rather than brain drain. Studies of the flow of knowledge, largely based on the location of persons who co-patent, suggest that immigrants work with persons in their birth country to produce and pass knowledge quickly through ethnic networks, which could compensate for the immigrant inventing products or processes overseas. Ethnic networks are also connected with trade flows and with multinationals forming new affiliates in countries, expanding manufacturing in those areas (Kerr, 2008 cited in Freeman, 2013) and in future foreign direct investment. The co-movement in skilled labour, trade and capital create unexpected economic outcomes in part because extant models do not explicitly treat the information and knowledge flows that are part of those movements.

\section{THE PRESSURES OF TRADE ON WAGES AND EMPLOYMENT}

The great fear of globalization critics was that increased trade between advanced and developing countries would adversely affect low skill workers in advanced countries and pressure developing countries to lower labour standards as they competed to attract foreign investments. Since unskilled labour is the relatively scarce factor in advanced countries, that trade would reduce unskilled wages relative to skilled worker wages fits with standard trade theory and pressures toward factor price equilibrium with trading partners. During the NAFTA debate, however, treaty advocates denied that trade would harm workers and dismissed factor price equilibrium as theoretically "far more frail than currently imagined" and rejected factor content evidence that trade reduces the wages of unskilled workers by increasing their implicit supply. As trade with developing countries has grown, particularly with China, this position has become untenable. Comparing local labor markets more or less affected by Chinese imports to the US, Autor, Dorn and Hanson (2012 cited in Freeman, 2013) find that greater import pressures increase unemployment, lower labour force participation, and reduce wages with parameters that "explains one-quarter of the contemporaneous aggregate decline in U.S. manufacturing employment". 
Diverse studies of the effect of offshoring find both wage and employment effects on workers, usually with evidence from the US. The result is not NAFTA opponent Ross Perot's "giant sucking sound "of jobs leaving advanced countries from trade, but pressures toward factor price equalization that show up in job displacement (which translates into lower wages on new jobs for the affected workers) as well as reductions in relative wages of workers in trade-impacted areas. In the 1990s-2000s the challenge to the factor proportions analysis of the effect of globalization on labour markets has come from a different quarter: "The 1990's dealt a blow to traditional Heckscher-Ohlin analysis of the relationship between trade and income inequality, as it became clear that rising inequality in low- income countries and other features of the data were in consistent with that model.

As a result, economists moved away from trade as a plausible explanation for rising income inequality... a number of new mechanisms have been explored through which trade can affect (and usually increase) income inequality ...within-industry effects due to heterogeneous firms; effects of offshoring of tasks; effects on incomplete contracting; and effects of labourmarket frictions." As an example of the more subtle analysis necessary to explain patterns in the data Amiti and Davis (2009) differentiate between falls in tariffs on outputs and falls in tariffs on inputs on the wages of workers in firms in different positions in the chain of production. The increase in skill differentials in developing countries with abundant unskilled labour is mindful of the Leontief Paradox: the finding that in the aftermath of World War II (and later) the capital rich US exported labour-intensive products while importing products that were capital-intensive. Part of the explanation seems to lie in the greater education or human capital that American workers had over workers in other countries in the period and part also to differences in knowledge, with US exports concentrated in R\&D and knowledge-intensive activities and imports coming from sectors with less knowledge-based activity (Keesing, 1967 cited in Freeman, 2013). Could the globalization of knowledge and knowledge creation have contributed to the increased inequality in developing economies in the 1990s? Since increased supply of graduates in developing countries operates to reduce labour market inequality, any knowledge-based explanation must rest on the impact of the supply of graduates and R\&D on modes of production that benefitted skilled labour versus unskilled labour. That rapid increases in GDP per capita in developing countries did not expand employment in manufacturing and other formal sectors enough to reduce the share of workers working informally in developing countries suggests that transfer of technology and knowledge may have played a role. Cross section data show a strong inverse relation between the informal sector share of a work force and GDP per capita that implies that in the past, economic development reduced employment rapidly in the informal sector. But in the 1990s-2000s the share of the work force in developing countries barely changed, making the informal normal.

The growth of global value chains - the fragmentation of production of goods and services into parts and tasks that could be offshored to many different countries - may also have changed the nature of globalization in ways that benefitted skilled workers in developing countries relatively to unskilled workers in the informal sector. Without gainsaying the 1990s increase in income inequality in some developing countries with globalization, evidence that income inequality fell in the 2000s in some of the same countries, including 12 of 17 Latin American (Gasparini and Lustig, 2011 cited in Freeman, 2013) also leaves open the possibility that the puzzle could be more about a temporary decadal phenomenon than about a long term relation.

\section{EFFECTS ON LABOUR STANDARDS}

The greatest fear of critics of globalization was that globalization would set off a race to the bottom in labour standards as developing countries competed to attract foreign investment and boost exports. Egregious cases of low standards among subcontractors to multinational firms such as the worker suicides at Foxconn (subcontractor to Apple) and the 2013 collapse of the eight-storey Rana Plaza factory building in Bangladesh that killed over one thousand employees of subcontractors for major garment firms notwithstanding, however, globalization tended to improve rather than reduce labour standards around the world. Why? One important factor was the spread of information about labour conditions that galvanized consumer pressures against bad working conditions. "Human rights vigilantes" - activists devoted to improving labour conditions in developing countries succeeded in getting some brand name firms to monitor suppliers, to improve conditions, to identify suppliers so that the activists could independently monitor how their suppliers treated workers, and to develop codes of conduct for themselves and their 
subcontractors. Developing countries enacted protective labour legislation and signed the ILO's conventions on labour standards (Freeman, 2013). In 2007 China enacted a new Contract Labour Law, which pressured firms to give written contracts to migrant and other workers and to pay legally required social insurance. Brazil increased its resources for implementing labour law. Pressed by unions and activists, the US, Canada, and some other advanced countries put labour standards clauses into trade clauses.

Examining the efforts of human rights and antisweatshop activists to improve working conditions and raise wages for workers in Indonesia, Harrison and Scorese concluded that "firms touched by the global market place were more, not less, likely to comply with labour standards (due in part) to ... pressure imposed by the United States, which used the GSP as a mechanism to enforce labour standards in Indonesia, combined with increasing human rights activism"(Harrison and Scorse, 2003, p 80 cited in Freeman, 2013). But they also note that while "activism significantly improved wages for unskilled workers in sweatshop industries, (it) probably encouraged some plants to leave Indonesia.". The job of the activists is to balance improvements in wages and labour conditions against the risk of job loss or plant closure from their campaigns Overall, the activists appear to have succeeded in doing this. In their review of job accident rates, child labour, and violations of civil rights in Asia, and the linkage between foreign direct investment and labour regulations among all countries, Flanagan and Khor (2012, p 280 cited in Freeman, 2013) concluded that "a broad improvement in working conditions and labour rights around the world accompanied a significant expansion of international trade and investment."

\section{CONCLUSION}

Globalization was accompanied by a huge spread of knowledge and knowledge production that influenced factor flows, productivity, and comparative advantage. It created some difficult adjustments for workers in both developing countries and advanced countries and produced worldwide pressures for better labour standards rather than creating a race to the bottom in standards. While globalization of knowledge and knowledge production may not be the key factor underlying the effects of globalization on labour, per my one ring analogy, the evidence in this paper has hopefully convinced scholars that the spread of knowledge is on par with the more widely studied trade, international capital flows, and immigration in determining outcomes and can help explain some otherwise puzzling patterns in the effects of globalization on labour. Additionally, a society which development and growth, competitiveness and innovation are driven by borderless spread of knowledge, African countries need to make vital and conducive atmosphere to cooperate. These countries need to welcome movement or dynamics and motivations driving an economic system. This can be buttress by the observation of Salkowitz (2010 cited in Freeman, 2013) that a globalise economy driven by scientific knowledge perpetuates a world where the arbitrary dictates of geography and history do not limit the potential of countries.

It is a universe where distance or language is no longer a barrier, interpretations and versions of ideas have been design to reach audience and meet a purpose, organisations are no longer defined by the natural resource endowment of nations. In a study by Evoh (2005), unveils that African countries are still afar behind the rest world in terms of knowledge and innovation-related policies and activities arising from their institutional, structural and educational weaknesses, and these have affected discoveries, inventions, new trends towards making development. The globalization of economic activity that has spread the benefits of modern technology around the world and helped improve living standards in traditionally low income countries produced some unexpected changes in the labour market and economy writ large (Freeman, 2013). Leaders in the continent of Africa need to put in place innovative strategies, ICT infrastructure and the prerequisite economic and institutional regimes to enhance its capacity in the global knowledge economy.

\section{REFERENCES}

Altbach, P.G. (1987). The knowledge context: Comparative perspectives on the distribution of knowledge. Albany, NY: State University of New York Press.

Altbach, P. G. (2004). Globalization and the university: Myths and realities in an unequal world. Tertiary Education Management, 10(1), 3-25. https://doi.org/10.1080/13583883.2004.9967114

Cunha, I.F. (2013). The globalization of research in Social Sciences: The case of Communication Studies in the Ibero-American and Lusophone Space

Dunning, John H. (2002). Regions, Globalization, and the Knowledge-Based Economy Rutgers University, Newark.

Ebohon, S.I. (2012). Globalization, Technology Transfer and the Knowledge Gap: Case Study of the Global Pharmaceutical Industry in Nigeria. Global Journal of Social Sciences Vol 11, No. 1, 2012: 21-31 
Evoh, C.J. (2005). ICT and African Transition to the knowledge Economy: Issues and Challenges Facing Nigeria in Funso Adesola, Iwebunor Okwechime, Ronke Ako-Nai and Iwilade (eds.) State, Governance and Security in Africa. SokheChapke Publishing, Inc. USA

Freeman, R. (2013). One Ring to Rule Them All? Globalization of Knowledge and Knowledge Creation. https://doi.org/10.3386/w19301

Freeman, Richard B. 2010b. "Globalization of scientific and engineering talent: international mobility of students, workers, and ideas and the world economy," Economics of Innovation and New Technology, 19: 5, 393-406. https://doi.org/10.1080/10438590903432871

Freeman, Richard B. and Remco Oostendorp. 2000. "Wages Around the World: Pay Across Occupations and Countries," NBER Working Papers 8058, National Bureau of Economic Research, Inc.

Krugman, P. (1979). “A Model of Innovation, Technology Transfer, and the World" Journal of Political Economy, Vol. 87, No. 2. https://doi.org/10.1086/260755

Kunal, D. (2008). Learning, Knowledge Diausion and the Gains from Globalization. Princeton University, Job Market Paper.

Muthayan, S. (2005). Globalization, Democratization and Knowledge Production At Three South. PhD thesis, The University of British Columbia.

Mokyr, J. (1990). The lever of riches: Technological creativity and economic progress. Oxford: Oxford University Press.

Norma, R. A. (2014). Indigenous Ways of Knowing and Possibilities for Re-Envisaging Globalization: Implications for Human Ecology. J Hum Ecol, 48(1): 123-133 (2014). Kamla-Raj https://doi.org/10.1080/09709274.2014.11906781
Obah-Akpowoghaha, N.G; B.T. Badejo and Ogunmilade, A. (2014). New-Technologies as A Recipe for Mitigating the ills of Capitalism And Underdevelopment in Africa. Australian Journal of Business and Management Research. Vol.4 No.1 pp.01-07

Perry, M. (2003). Distributed Cognition. In J. Carroll (Ed.), HCl Models, Theories, and Frameworks: Toward an Interdisciplinary Science, pp. 193-223. San Francisco, CA: Morgan Kaufmann. https://doi.org/10.1016/B978-155860808-5/50008-3

Peter, S. (2016). Internationalization Strategies for the Global Knowledge Society. Canadian Bureau for International Education, CBIEPhDRESEARCH. cbie-bcei.ca

Renn, J and Hyman, M. (2013). Globalization of Knowledge. Forschungsperspektiven

Jones, R. W. and Ruffin, R.J. (2007). "International Technology Transfer: Who Gains and Who Loses?" Review of International Economics 15(2): 209-222. https://doi.org/10.1111/j.1467-9396.2007.00644.x

Storper, M. (1999). Globalization and Knowledge Flows. Oxford: Oxford University Press

Shimelis, G. A. (2009). Unfulfilled promises of globalization: Global knowledge production and Africa. https://www.researchgate. net/publication/280661493

Stiglitz, J. E. (nd). Globalization and growth in emerging markets and the New Economy. Journal of Policy Modeling. Columbia University, New York, NY 10027, USA.

Westermann, M.; Fisher, C. (nd). Where is "Knowledge" in the Globalization of Higher Education and Research? Introductory Panel in AFAvH Pilot Series. German Centre for Research and Innovation, New York

\section{DOI: https://doi.org/10.6000/1929-7092.2019.08.02}

\section{(c) 2019 Kelvin Bribena; Licensee Lifescience Global.}

This is an open access article licensed under the terms of the Creative Commons Attribution Non-Commercial License (http://creativecommons.org/licenses/by-nc/3.0/) which permits unrestricted, non-commercial use, distribution and reproduction in any medium, provided the work is properly cited. 